\title{
HISTORY
}

\section{THE EFFORTS OF KING ABDULLAH II BIN AL HUSSEIN TO PROTECT ISLAMIC SANCTITIES}

\author{
Dr. Hadi Mahasneh, Aqaba University of Technology, Aqaba, Jordan
}

DOI: https://doi.org/10.31435/rsglobal_ws/30122019/6837

\section{ARTICLE INFO}

Received: 17 October 2019

Accepted: 23 December 2019

Published: 30 December 2019

\section{KEYWORDS}

Islamic,

historic,

sanctities,

efforts,

reconstruction,

descriptive.

\begin{abstract}
The purpose of this study was to present the efforts of King Abdullah II to protect the Islamic shrines, and this was done using a historical approach and a descriptive analytical approach that identifies the origins of the Hashemites and their ongoing efforts to restore the Islamic shrines, then it was first identified and the second reconstruction of the Hashemites. Finally, third, King Abdullah II's efforts were made to monitor the Hashemite ancestors in restoring and protecting Islamic and Christian holy sites, and at the end of the study, potential outcomes of King Abdullah II's efforts to restore and protect Islamic holy sites were identified. He called for a series of results, the most important of which is that King Abdullah II reiterated his real and practical interest in restoring and protecting Islamic holy places after the campaign of his Hashemite ancestors.
\end{abstract}

Citation: Hadi Mahasneh. (2019) The Efforts of King Abdullah Ii Bin Al Hussein to Protect Islamic Sanctities. World Science. 12(52), Vol.2. doi: 10.31435/rsglobal_ws/30122019/6837

Copyright: (C) 2019 Hadi Mahasneh. This is an open-access article distributed under the terms of the Creative Commons Attribution License (CC BY). The use, distribution or reproduction in other forums is permitted, provided the original author(s) or licensor are credited and that the original publication in this journal is cited, in accordance with accepted academic practice. No use, distribution or reproduction is permitted which does not comply with these terms.

Introduction. The Fourteenth Islamic Summit Conference, which concluded its work in Makkah Al-Mukarramah several months ago, praised the efforts made by the Hashemite Kingdom of Jordan and the role of His Majesty King Abdullah II Ibn Al-Hussein, the guardian of Islamic and Christian holy sites in Al-Quds Al-Sharif, in defending, protecting and preserving the city of Jerusalem and its Islamic and Christian sanctities, It supported the steadfastness of its Arab Palestinian residents of Jerusalem on their land in the face of illegal Israeli violations and measures aimed at changing the Arab-Islamic and Christian identity of the city, and renewed its rejection of all Israeli attempts affecting care The tutelage of the historic Hashemite which reaffirmed the important agreement signed between His Majesty King Abdullah II Ibn Al Hussein, King of the Hashemite Kingdom of Jordan, and President Mahmoud Abbas, President of the State of Palestine in Amman, March 31, 2013.

Article (d) of the introduction to this agreement stipulates that: "And based on the role of the honorable King Hussein Bin Ali in protecting and caring for holy sites in Jerusalem and their reconstruction since 1924, and the continuation of this role continuously in the Hashemite Kingdom of Jordan's King from the dynasty of Sharif Hussein bin Ali Until today, based on the pledge of allegiance according to which the guardianship of the holy places of Sharif Al-Hussein bin Ali was confirmed, and that was confirmed by his pledge of allegiance on March 11, 1924 by the people of Jerusalem and Palestine. The guardianship of the holy places in Jerusalem was transferred to His Majesty King Abdullah II Ibn Al-Hussein Including the Greek Orthodox Patriarchate Jerusalem, which is subject to Jordanian law No. (27) for the year 1958, and Article (e) of the same article affirms the continuous care of Abdullah II for the holy places, making him the most capable of protecting Islamic holy sites and maintaining Al-Aqsa Mosque.

Research problem. Islamic sanctities, headed by Jerusalem, are an integral part of the Jordanian constants, and these matters are clearly shown through the Hashemite patronage of these sanctuaries, where 
Sharif Al-Hussein Bin Ali carried out the first Hashemite reconstruction, and King Abdullah I continued this patronage, and this patronage continued during the era of King Talal, and King Hussein Bin Talal, who ordered the issuance of the Reconstruction Committee for the Blessed Al-Aqsa Mosque No. (32) for the year 1954, and the second and third reconstruction process continued during the reign of King Hussein, during which the maintenance and restoration of buildings, domes, squares, the Dome of the Holy Rock, and Al-Aqsa Mosque ( Tribal) which was done Preserving all its decorations and flanks, as King Abdullah II Ibn Al-Hussein (Al-Husayn) walked along these steps. Hence, the research problem consists in a key pivotal question that says: What are the efforts made and still being made by King Abdullah II Bin AlHussein in protecting Islamic sanctities?

The main question of the research question arises from the following sub questions:

1 - What is the historical role that the Hashemites played in protecting Islamic holy sites?

2- What is the mechanism followed by King Abdullah II to protect Islamic sanctities today?

3- What are the expected prospects for King Abdullah II's efforts to protect Islamic holy sites, present and future?

Research importance. The importance of this research stems from the importance of Islamic sanctities, and specifically the importance of Jerusalem, as it is the first of the two kisses, in which the Al-Aqsa Mosque is the Al-Aqsa Mosque, the second mosque after the Forbidden Mosque, and the AlAqsa Mosque in Jerusalem is the third of the two holy sites in status after the Grand Mosque and the Prophet's Mosque Also, the importance of this study comes from the fact that the land of Jerusalem is a blessed land, as it is the land of prophets, and the path of the Messenger of God, may God bless him and grant him peace, on the journey of Israa and Mi'raj.

Research Methodology. The nature of this research requires resorting to the historical approach to get acquainted with the history of Jerusalem, the history of the Hashemites, and the descriptive and analytical approach to get acquainted with the reality of the status of Islamic holy sites, and Al-Aqsa Mosque, and it is also necessary to resort to the prospective approach in order to identify the issues that will result from the protection of Islamic holy sites, and Jerusalem in Next time, especially during and after the deal of the century.

\section{Search limits:}

This research will have the following limits:

Time limits: From the noble prophetic mission until the date of preparing this research.

Spatial boundaries: The spatial boundaries for this research will extend from the land of Hijaz to Jordan and Palestine.

Objective limits: This study will have three main topics: the efforts of King Abdullah II, the Hashemites, and Islamic sanctities.

\section{Search Plan:}

Based on the above, the study came in the introduction and three sections, so that the first topic talks about the historical role that the Hashemites played in protecting Islamic sanctities, while the second topic talks about the mechanisms that King Abdullah II followed and followed to preserve and reconstruct Islamic sanctities, while the third topic talks On the expected prospects for the efforts of King Abdullah II in the reconstruction of Islamic holy sites, especially the Al-Aqsa Mosque, in the coming time, and the study ends with a conclusion that includes the results of the study, followed by references on which the study relied.

\section{The first topic:}

The historical role the Hashemites played in protecting Islamic holy sites:

The children of Hashem retained the leadership of the Quraysh dynasty, and they continued to represent the vanguard of society in the Hijaz, as a moral elite and the people of political and economic management, and they enjoyed the appreciation and respect of visitors to the Sacred House, and in modern history, the Hashemites led the Arab revolution towards building a unified state, where the launch of the Great Arab Revolution in 1916 The first step to independence, and without them, it is worth protecting the religious and national heritage.

Based on the foregoing, the topic of this topic will be addressed through two requirements, the first talks about the establishment of the Hashemites and the establishment of the Jordanian Emirate, while the second demand speaks about the role of the Hashemites in protecting Islamic sanctities throughout history.

The first requirement:

The emergence of the Hashemites and the establishment of the Jordanian emirate 
First: The emergence of the Hashemites

Ibn Taymiyyah said: Quraysh is the best of the Arabs, that Bani Hashem is the best of Quraysh, and that the Mustafa, peace and blessings of God be upon him, is the best of Bani Hashem. He is the best of people, soul and lineage. Hashim was left only after Abd al-Muttalib only (), and to whom the Hashemites are affiliated, and Hashim is the second grandfather of Muhammad, peace and blessings be upon him, and he was the first to initiate the winter and summer trips, where he came in the download court: !lllaf Quraish \&Illafah $\lrcorner$ Rahala ((, And his name is: Hashem Amr Ibn Abd Manaf, and what you call him Hashem is only for his quantities of bread, And feeding his porridge people with a net, which happened in the year of famine, because his people from Quraish were afflicted by drought, so Abd al-Muttalib went to Palestine and bought flour, and he brought it to Mecca, so he ordered him to complete his bread, then slaughter and carrots, and then he took his people from his broth as a bread with that bread [1].

It came in the Ansab Al-Arab crowd: As for Kaab bin Loay, Fuld Marra, Fuld Marra bin Kaab bin Loay: Kulab bin Marra, Fuld Kalab bin Marra: Qusay bin Kulab, Fuld Qusay bin Kalab: Abdul Manaf, Fuld Abdul Manaf bin Qusay: Amr He is Hashem, and Al-Muttalib; Abdul Shams; and Nofal. Fuld Hashem bin Abdul Manaf: Shaybah, and he is Abdul-Muttalib, and he has the pillar and honor, and only Hashem is left after Hashem [2].

Second: Establishing the Jordanian Emirate:

1- Introduction: It is known that the Sykes-Picot Agreement divided the Arab states, and with the decisions of the San Remo conference, Syria and Lebanon were subject to direct French military occupation, while the southern Yarmouk River and the east of the Jordan River came under British influence, and thus the region became a passageway between Iraq in the east and Palestine In the west, where this region formed the southern part of natural Syria, so it was included in the Syrian kingdom and subjected to its administrative divisions, until the French eliminated it after the Battle of Maysaloon [3].

2- Prince Abdullah's arrival in Jordan: After King Faisal bin Al-Hussein was compelled to leave Damascus, Prince Abdullah bin Al-Hussein requested permission from his father, King Hussein bin Ali, of Al-Hijaz at the time, heading towards the Levant. He arrived Ma'an on (21/11/1920). ), And the people of Ma'an and the people of her country welcomed him with enthusiasm and love, and he was among those who received him at that time: Prince Ghaleb Al-Shaalan, President Abdel-Qader Al-Jundi, President Muhammad Ali Al-Ajlouni, Khalaf Al-Tal, Ahmed Al-Tal, and others [4].

Prince Abdullah announced his specific goal, which is to liberate Syria from colonialism () in the publication he edited on (25/11/1920), titled to all our Syrian brothers [5], and in the meantime, King Faisal bin Al Hussein met the King of Britain, George V, who He told him that the Arabs should do nothing to irritate the French against extending the Arab issue to the table again, so King Faisal asked his brother, Prince Abdullah, for moderation, and despite this, Prince Abdullah marched from Ma'an to Amman, where he arrived on (2/3 / 1921), and was received by the then British officer Allen Kirkbride.

The important thing in the matter is that Prince Abdullah traveled to Jerusalem and held a conference that lasted for two days in a row between (28-29 /3/1921) with Churchill. This meeting produced important results, the most important of which was: Establishing a national government in the East of Jordan headed by Prince Abdullah bin Al-Hussein, and this government is administratively independent, and Britain provides financial assistance to spend on security, and Prince Abdullah pledges to maintain the borders of Palestine and Syria, we were entitled to Britain to establish two aviation bases in Amman and Zeesat, and the duration of this agreement was six months subject to extension, and the formation of the first government in (11/4/1921), Amman became the capital of the country, which included Three areas are: Ajloun, Balqa, and Moab. It can be said that in 1921 the Emirate of Transjordan was created, on which Prince Abdullah bin Al-Hussein was installed as Emir [7].

Britain demarcated the borders of this emirate in agreement with the French side. In 1921, France separated Ramtha from Syria and annexed it to Transjordan, while Abdulaziz Al Saud ceded the regions of Maan and Aqaba in 1925; the area of Transjordan then reached 91,000 km 2, Of these, 10,000 km2 are fertile agricultural lands located in a $65 \mathrm{~km}$ wide strip in the north, and 450 villages are considered. The names and borders of the Ottoman brigades: Ajloun, Balqa, and Karak remained the same, and the Ma'an Brigade was added to it in 1925, and the development and establishment of brigades and provinces continued, as did the development of It was during the Ottoman era, within the framework of the central government policy aimed at the settlement of Bedouins He is gone, and to control the lands, in addition to controlling the borders. After the establishment of the emirate, all these brigades were limited to the east by the Hejaz Railway, at the 250 $\mathrm{mm}$ rainfall line, where rainfed agriculture areas begin in the desert [7] (see Map 1). 


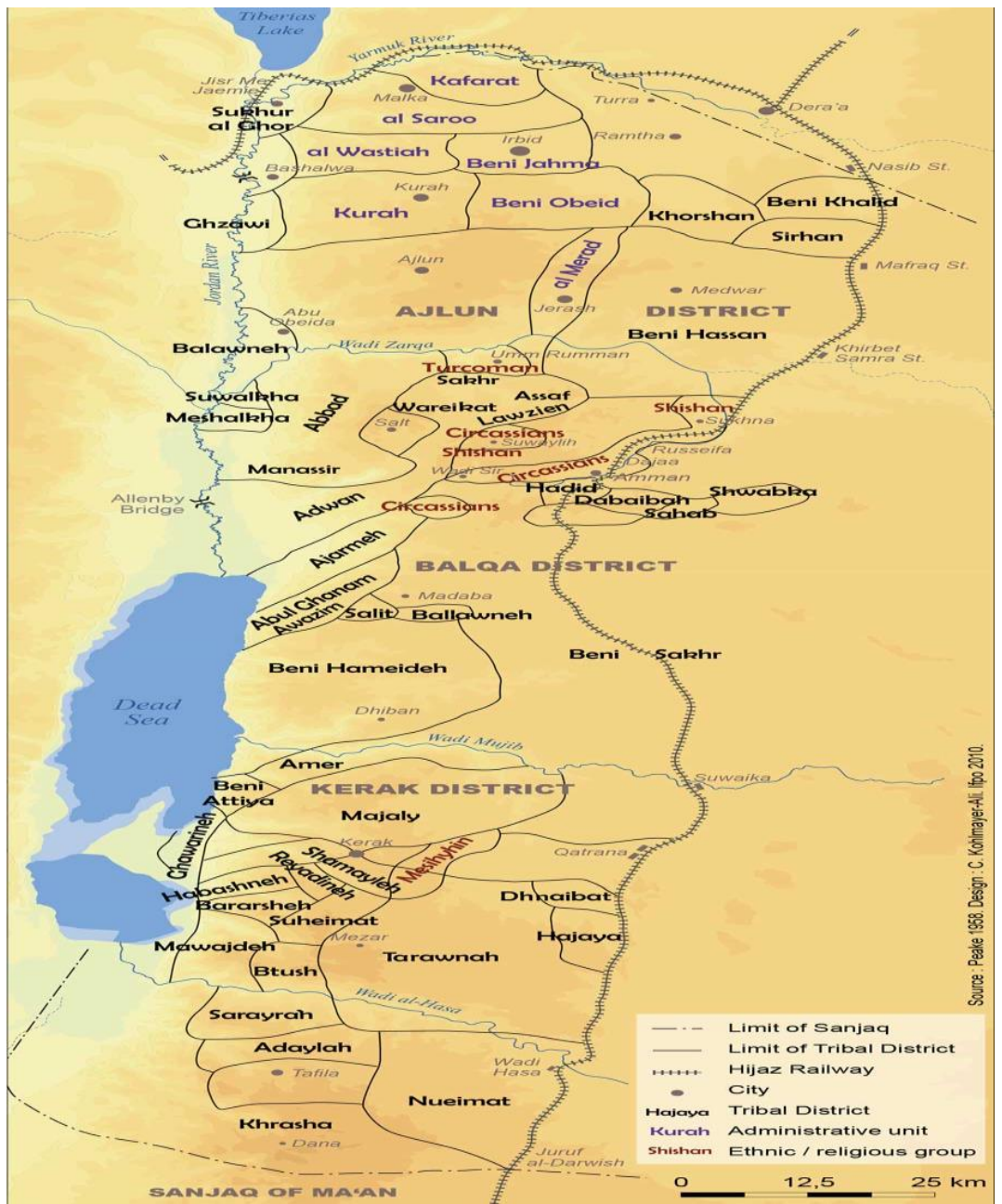

Fig.1. Map (1) the areas (fronts) of the major Jordanian tribes and tribes in 1929.

\section{The second requirement:}

The role of the Hashemites in protecting Islamic sanctities throughout history:

Hashemite attachment to Islamic sanctities appeared since the era of Sharif Al-Hussein Bin Ali in the year (1924) through his full sponsorship of these sanctuaries, especially Jerusalem, and through the material and moral support he provided to the reconstruction of Jerusalem, which is considered its reconstruction from the Hashemite message that they carried throughout history until today, Their interest in these sanctuaries, especially Jerusalem, was evident through the successive buildings they undertook to preserve these sanctuaries. The first, second, and third ages that the Hashemites undertook to protect these sanctuaries will be discussed.

First: The First Hashemite Reconstruction:

The Arab region in particular, and the Islamic world in general at the beginning of the last century, was subjected to the maximum of a crusader colonial attack, and despite the gravity of the events that the region was subjected to, the leader of the Great Arab Revolution Hussein bin Ali did not forget Jerusalem, so he presented to those in charge of it the men of the Supreme Islamic Sharia Council Financial and moral support, as he allocated an amount of $(24,000)$ dinars that went to his construction and the preservation of this mosque, although he was in dire need of this amount when he was leading the nation's liberators to achieve freedom and Arab unity, but his interest in Jerusalem and his love for the maximum was paying him for all aspects of giving and giving to his reconstruction And the governor It is necessary for him to maintain and maintain it, and the documents saved in Jerusalem indicate that he was following the work of the Reconstruction Committee, continuing his directives to them and expressing great love and appreciation for their efforts, so that he recommended that he be buried in the sanctuary of the Noble Sanctuary so that his children and grandchildren from after him would preserve this mosque [8].

And it came on the website of King Abdullah II that the amount donated by Hussein bin Ali is fifty thousand gold dinars for the reconstruction of Al-Aqsa Mosque and other mosques in Palestine, 
to form the basis of Islamic money for the construction of holy sites, thus fulfilling the call of the people of Jerusalem as the first responders, when a Jerusalem delegation visited him in 1924 AD In Al-Hijaz, headed by Haj Amin Al-Husseini, head of the Supreme Islamic Legislative Council, and briefed on the dangers to Al-Aqsa Mosque, the restoration process that Al-Sharif Al-Hussein Bin Ali blessed in Jerusalem was contributing to the steadfastness of the facilities of Al-Aqsa Mosque when a violent earthquake struck the region in 1927 [9].

Second: The Second Hashemite Reconstruction [10]:

Once King Hussein bin Talal assumed his constitutional powers, he placed Islamic sanctities, headed by Jerusalem and the blessed Al-Aqsa at the forefront of his priorities, where he issued decrees forming the Committee for the Reconstruction of the Blessed Al-Aqsa Mosque and the Dome of the Rock honored by Law No. 32 of 1954, and since that time has taken care of Islamic sanctities By the Hashemites the character of consistency, permanence and continuity, and for the Hashemite patronage of Islamic holy sites to be a fixed historical and legal right, and with the kind guidance of King Hussein bin Talal - may God rest his soul - the commission in charge of reconstruction has carried out a comprehensive study of the status of the sanctities in Al-Quds Al-Sharif, and Wadd I developed an integrated plan for its reconstruction in accordance with the technical principles and rules. Perhaps the most prominent achievements of this committee during that period are the following:

1- Reconstruction of the Al-Aqsa Mosque building, restoration of its walls, columns, corridors, windows, and all the decorations it contains.

2- Preserving the Islamic landmarks in Al-Haram Al-Sharif Square and its wells, avenues, domes, terraces, and mihrabs.

3- The comprehensive reconstruction of the Dome of the Noble Dome, which included:

A- Re-covering the Dome of the Rock in Yellow Aluminum.

B- Re-clad the dome corridors with white aluminum.

C- Restoration of the entire Qashani and the marble that surrounds the vaulting of the dome from the outside and the signs and decorations it contains.

D- Restoring the restoration of the interior decoration in the dome building and the columns and interior marble that the building includes.

Third: The Third Hashemite Reconstruction [11]:

The Third Hashemite Reconstruction took place after the Zionist enemy occupied Jerusalem, but the Islamic Endowments continued to be fully linked to the Jordanian Ministry of Endowments and Islamic Holy Affairs. This ministry also allocated material and moral support to its devices that remained operating throughout the occupied West Bank, and allocated half of its annual budget. To take care of mosques, colleges, institutes, religious schools, and imams, and everything necessary to protect the Arab-Islamic heritage in the city of Jerusalem. The Third Hashemite Reconstruction coincided with the occurrence of the West Bank, including Jerusalem, under the Israeli occupation. Nevertheless, the Islamic Waqfs remained totally affiliated to the Jordanian Ministry of Endowments, Affairs and Islamic Shrines, which in turn set an annual budget for the care of Islamic shrines and endowments, which includes: mosques, colleges, institutes, Schools in Jerusalem aim to preserve their Arab-Islamic identity.

\section{The second topic:}

The mechanisms followed and followed by King Abdullah II for the preservation and reconstruction of Islamic holy sites:

Once King Abdullah II received his constitutional powers on February 7, 1999, he began completing the Hashemite march, on the topic of Islamic sanctities, headed by Jerusalem. In an interview with him for the Lebanese Journal of Events on September 17, 1999, he said: "Jerusalem is for us an occupied Palestinian land that applies to it. The rest of the occupied Palestinian territories ... We support and support the Palestinian brothers to reach a full ... We believe that the Palestinian issue is the core of the conflict in the Middle East, and that the desired peace cannot be achieved without a just settlement of this issue [12].

King Abdullah II was keen on taking care of Islamic holy sites, foremost of which is Jerusalem, where he issued the Hashemite Fund Law for the Reconstruction of the Blessed Al-Aqsa Mosque and the Dome of the Holy Rock No. 15 of 2007, and this fund aims to provide the necessary funding for the care of the Al-Aqsa Mosque and Islamic holy sites in Jerusalem to ensure continuity Its construction, maintenance, and provision of all the necessary requirements for it. Article 4 of this law stipulates that: "The fund aims to provide the necessary funding for the care of the blessed Al Aqsa Mosque, the Dome of the Holy Rock, and Islamic holy sites in Al Quds Al Sharif to ensure the continuity of the reconstruction. A, maintenance, 
processing, and provide all the necessary requirements to confirm the importance of these holy sites and the sanctity of the Muslims in general and the Hashemites in particular."

Based on the foregoing, the subject of this topic will be addressed through two requirements, the first talks about the fourth Hashemite reconstruction during the reign of King Abdullah II, while the second demand talks about the reconstruction of the mosques of the prophets and the companions and their residencies in Jordan during the reign of King Abdullah II.

\section{The first requirement:}

Fourth Hashemite reconstruction during the reign of King Abdullah II.

Islamic and Christian sanctuaries were and still are the primary concern of the Hashemites, so it is not surprising that these sanctuaries become an integral part of the work programs of Jordanian governments during the reign of King Abdullah II. He followed the Hashemite march with the fourth Hashemite reconstruction projects, which included: the pulpit of the blessed Al-Aqsa Mosque, the southern wall of the Al-Aqsa Mosque, the eastern wall of the Al-Aqsa Mosque, the project of a system of tensile bars and fastening of the walls of the Marwani prayer room, the alarm system and extinguishing the freedom S in the Al-Aqsa Mosque, structures and infrastructures, the Dome of the Holy Rock, the Nativity of Jesus, peace be upon him, and the restoration of the Holy Sepulcher, and in it is a detail:

First: The pulpit of the blessed Al-Aqsa Mosque:

This platform embodies the victory over the occupied Franks, as it was used by Salahuddin $\mathrm{Al}$ Ayyubi after the liberation of Jerusalem in the year 1187 AD. Therefore, some call it the platform of Salahuddin, and this platform historically embodies a unique masterpiece of its kind, as there is no platform similar to it in its size or the size of the decorations in it that relied on interlock, and engraving on wood on both sides [14]. King Abdullah II was honored to place the first decorative painting on the body of the platform on 26 Ramadan $1423 \mathrm{AH}$, corresponding to December 1, 2002, and the work in the manufacturing process issued interest and continuous follow-up, so that the platform would return to its true distinctive image with great goodness, accuracy and perfection, as he wanted him to King Hussein bin Talal, may God rest his soul, be pleased when he instructed to remake the Salah al-Din al-Ayyubi minbar on Rabi al-Awal 10, 1414 AH, corresponding to August 28, 1993 AD. It took four years to prepare this platform at a cost of $(2,200)$ two million two hundred thousand dinars. He was placed in his place at the AlAqsa Mosque in the month of Cannes The second Wen of 2007 [15].

Second: During the fourth reconstruction during the reign of King Abdullah II, the southern and eastern walls and the walls of the Takhtian school were restored, and a fire alarm system was implemented in the blessed Al-Aqsa Mosque with the best international specifications, and the Holy Mosque was provided with (10) firefighting vehicles drawn in cooperation With the Jordanian Civil Defense, in addition to the above, the stucco and mosaic motifs, the interior marble and the interior decorations of the roof and walls in the Dome of the Holy Rock were restored. Parts of it, such as acoustics and lighting projects [16].

Third: Restoration of the Holy Sepulcher: On April 4, 2016, with a Royal Decree, King Abdullah II donated, at his own expense, the restoration of the Holy Sepulcher in the Church of the Holy Sepulcher in Jerusalem. Patriarch Kyrius Theophilus III, Patriarch of the Holy City and all other works of Jordan and Palestine [17].

The second requirement:

Islamic sanctities in the politics of King Abdullah II:

The question of Jerusalem has been and remains the most important axis in King Abdullah II's policy since he assumed his constitutional powers in 1999, and about Jerusalem and the sanctuaries. The Secretary General of the Islamic Christian Authority for the Support of Jerusalem and the Holy Sanctuaries Hanna Issa asserted that the Hashemite guardianship of Islamic and Christian sanctities in Jerusalem, especially the blessed Al Aqsa Mosque It was a protective shield in protecting these holy sites from Judaization and seizure by the Israeli occupation and its extremist settlers.

To get acquainted with the positions of King Abdullah II in his support for Islamic holy sites, we will resort to a meeting conducted by the Jordan News Agency Petra with the Secretary-General of the Royal Committee for Jerusalem Affairs Abdullah Kanaan, who monitored the most important of these positions and areas of royal support for Jerusalem and Islamic and Christian holy sites in it and the efforts made to support and support Jerusalemites stationed in the land of Jerusalem Sharif [18].

First: In the field of Hashemite Reconstruction of Jerusalem:

Since King Abdullah II assumed his constitutional powers in 1999, a number of reconstruction projects have been implemented by His Majesty's order, which is known as the Fifth Hashemite 
Reconstruction which included the project to rebuild the Salah al-Din Forum, where he placed on the twenty-seventh of the month of Ramadan in $2002 \mathrm{AD}$ the basic decorative painting of the platform at $\mathrm{Al}$ Balqa University Applied at the Faculty of Islamic Arts, and on the twenty-fifth of July 2006, His Majesty removed the platform of Salahuddin at Al-Balqa Applied University, marking the beginning of the process of returning the platform to the Al-Aqsa Mosque, embodying the Hashemite keenness to reconstruct and build Islamic holy sites.

Second: The project to renew the brushes of the Dome of the Holy Rock Mosque:

To implement this project, King Abdullah II donated enough to implement the needs of the Al-Aqsa Mosque with the necessary maintenance, the lighting project, the repair of the telephone network, and the installation of an integrated audio system for the Al-Aqsa Mosque, the Dome of the Holy Rock, and the Marwani Mosque.

Third: The Hashemite Guardianship of Jerusalem:

On May 31, 2013 the Hashemite guardianship of Jerusalem and the holy sites of King Abdullah II was renewed by signing an agreement between King Abdullah II and President Mahmoud Abbas.

Fourth: On the Arab and international level: King Abdullah II affirmed in all Arab conferences and summits that preserving Jerusalem and Islamic and Christian holy sites has an Arab national duty, while King Abdullah II employed all means of visits, contacts, and meetings with a number of Western countries leaders, opinion leaders, and the media It made unremitting efforts to preserve the identity of Jerusalem, and his diplomatic endeavors had the greatest impact in preventing Israel repeatedly from continuing its violations against Islamic and Christian religious sites in the city of Jerusalem, as he always affirmed during all his meetings in international forums with every p Comfort and clarity that Jerusalem, as it is the key to peace, is the key to war as well, and that a just, comprehensive and lasting solution to the Palestinian-Israeli conflict will only be through the establishment of an independent Palestinian state with Jerusalem as its capital.

The role of King Abdullah II has been clearly demonstrated in protecting Islamic and Christian holy sites at the global level through the formulation and issuance of many international resolutions by UNESCO, the General Assembly of the United Nations and the Security Council, including persuading members of the World Heritage Committee to reject the Israeli project submitted to build the Mugrabi Bridge by By an international decision through UNESCO, which considered the Israeli move an attack on history and civilization, while it approved the Jordanian project.

The Jordanian efforts led by King Abdullah II resulted in the Executive Council of UNESCO adopting Resolution No. 40 of 2016, the most important of which are:

1- Emphasis on naming the Al-Aqsa Mosque / Al-Haram Al-Qudsi and not the Temple Mount, and that this mosque is one of "pure Islamic sanctuaries", and the Jews have no connection with it.

2- Requesting Israel to allow a return to the historical situation that existed until September 2000, as the Jordanian Islamic Endowments Department was the only authority supervising the affairs of the mosque.

3- The decision considered the Hill of the Mughrabi Gate and the Buraq Wall to be integral parts of Al-Aqsa Mosque, and rejected the unilateral Israeli measures.

4- The resolution condemned the increasing Israeli aggressions and illegal measures to which workers in the Islamic Endowments Department are subjected and which limit Muslims' enjoyment of freedom of worship and their access to Al-Aqsa Mosque.

5- The decision strongly condemned the continued incursion into Al-Aqsa Mosque by Israeli right-wing extremists and the Israeli regular forces.

\section{The third topic:}

The expected prospects for the efforts of King Abdullah II in the reconstruction of Islamic holy sites.

The Hashemite guardianship of Islamic holy sites is a historical responsibility that the Hashemites committed to since the establishment of the Hashemite Kingdom of Jordan, and King Abdullah II remains faithfully and dedicatedly to this historical responsibility. Evidence for this is the trusteeship agreement signed between King Abdullah II and Palestinian President Mahmoud Abbas in 2013, Which emphasized that the care and supervision of the affairs of the holy sites in Jerusalem is for the Hashemites and the Jordanian state.

To get to know the expected prospects, we can say that we have two options: the scenario of despair and the scenario of hope for a two-state solution, and this is what we will get to know through the following two requirements: 


\section{The first requirement:}

Despair scenario:

This scenario includes several possibilities: The Jerusalem scenario is a life-long capital for Israel, the second scenario is the internationalization scenario, and the third is the partition scenario, and there is some detail in it:

First: The Jerusalem scenario is a life-long capital for Israel

This scenario expects the perpetuation and continuation of the status quo, including the usurpation, occupation and denial of the rights of the Palestinian people, and whether this path is related to separating what is religious from what is political, or is it confined to keeping Jerusalem united as the eternal capital of Israel, according to the Trump Declaration, which will threaten its continuation not By boycotting, it would also pose a real threat to regional peace in the Middle East. After Trump announced his administration's recognition of Jerusalem as the capital of Israel, he also directed the State Department to "start preparations for the transfer of the American embassy from Tel Aviv to Jerusalem." In 1995, Congress adopted by a large majority of both parties the Jerusalem Embassy Law, which stipulated that the American embassy should be moved to Jerusalem in a time limit not exceeding May 31, 1999. However, that law included a clause allowing the American President to sign a six-month waiver if he saw It is necessary to "protect American national security interests." Since the administration of President Bill Clinton and successive US administrations, the exemption is automatically expected every six months, even though they had promised as candidates to move the US embassy from Tel Aviv to Jerusalem [19].

It is worth noting that it is not the first time that the United States of America has attempted to declare Jerusalem as a unified capital of Israel. The Senate issued a resolution in April 1990 considering Jerusalem as the capital of Israel, and despite this contradiction with international law and relevant international resolutions, led by Resolution No. (181) The partition decision issued on $11 / 29 / 1947$, by which Israel granted (53\%) of the area of Palestine, but Jerusalem was not within this percentage, and it is not permissible to transfer lands legally until after a treaty has been concluded between the two parties, and so far there is no Any treaty between Israel and its Arab neighbors regarding Jerusalem, which means a The process of annexation of Jerusalem is considered legally invalid, so the Senate's decision to consider Jerusalem the capital of Israel is null and void [20].

Second: Internationalization scenario:

The roots of this scenario are related to the aforementioned Resolution (181) which stipulated that Jerusalem be a separate region located between the Arab and Jewish states, and subject to a special international system, and it is managed by the United Nations by a trusteeship council established for this purpose, and internationalizing the Palestinian issue means that the Palestinian issue becomes Either at the level of reference of the current political rights of the Palestinian people, or at the level of the mechanism for resolving the conflict with Israel of concern and competence of the United Nations and its specialized organizations and bodies, and that the national struggle in all its forms be inconsistent with them, and thus exit from the box of bilateral negotiations between an organization Liberation and Israel, which were governed by the principle of reason (the Oslo agreement), the law of the contractors, without a clear international reference to the negotiations and their results [20].

Third: Partition scenario:

This scenario is related to the hypothesis of returning matters to what they were before the June 1967 aggression, when Israel occupied Al-Quds Al-Sharif, a scenario that is based on the one hand on the principles of international legitimacy expressed by the decisions of both the General Assembly and the Security Council, and this scenario finds its strong support in the law International support and the full support of the United Nations, because the military occupation cannot lead to the transfer of sovereignty from the owner of legitimate sovereignty over the territory to the occupying Power, but rather gives it temporary powers in order to enable it to administer the region [17].

\section{The second requirement:}

The scenario of hope is a two-state solution:

The term "two-state solution" refers to a settlement of the Israeli-Palestinian conflict, based on the regional division of the historical area of Palestine between two states, Israel and Palestine. This term is based on its current political formula on the basis of the establishment of a Palestinian state within the borders of June 4, 1967, meaning the comprehensive areas of the West Bank, including Jerusalem. East and Gaza Strip, which constitutes about 22\% of the area of historic Palestine, as it is 
based side by side and on the basis of mutual recognition with the State of Israel already existing since 1948 on about 78\% of the historical area of Palestine, and in most cases the settlement contained in the agreements is linked to adding The vague sentence is to find a just solution to the Palestinian refugee issue based on United Nations resolutions No. (242) and (388), which Israel deliberately opposes to preserve the Jewish character of Israel [18].

King Abdullah II believes that "establishing stability in the Middle East region cannot be achieved without a just and lasting solution to the Palestinian issue on the basis of the two-state solution and the Arab peace initiative, and therefore the Palestinian people can attain their just and legitimate rights to establish their independent state on the lines of June 4, 1967 And its capital is East Jerusalem. "In a speech he delivered in the recent Arab emergency summit in Makkah AlMukarramah, it said:" Brothers, Arab leaders, honorable audience: The consolidation of stability in the region cannot be achieved without a just and lasting solution to the Palestinian issue based on the twostate solution and the Arab Peace Initiative. " E, can the Palestinian people to attain fair and legitimate rights in an independent state on the establishment of the fourth lines of June 1967, with its capital in East Jerusalem [18].

In the period between 2015-2017, the two-state solution witnessed a great dilemma for the Palestinians due to Israel's continued work to settle this issue, followed by Palestinian efforts and efforts to discuss the available options, including highlighting the option of a one-state solution (despite its historical presentation and its adoption by various parties) This is a Palestinian response to Israeli practices and the failure to implement the two-state solution, but it must be pointed out here that there are vague articles on the issue of the two-state solution that have not been discussed, which are summarized in the following points:

1- The Jewish character of Israel.

2- Refugees rights and a permanent solution to their issue, which was originally centered on returning to their homes inside Israel and not in the Palestinian territories occupied in 1967.

3- The fate of the Palestinian citizens inside Israel.

But the international community did not stand up to it towards the two-state solution, and it continues to raise the issue in various forms, and it can be said that the international community is still limited in dealing with issues that concern Israel, especially since the United States of America is still hindering any international move against Israel, The United States of America also continues to provide cover and permanent support to it [20].

Despite all of the above, King Abdullah II's efforts will continue and will continue to preserve and reconstruct Islamic holy shrines. In Jordan, there is the Directorate of the Blessed Al-Aqsa Mosque in the Ministry of Endowments. It is one of the districts concerned with the affairs of the blessed Al-Aqsa Mosque and Islamic Endowments in Al-Quds Al-Sharif and consists of the following sections The Al-Aqsa Mosque Department, the Studies and Information Department, the Waqf Properties Section, and the Al-Aqsa Mosque Projects Section; it tracks everything related to Islamic Waqf matters in Jerusalem, the Al-Aqsa Mosque, and the Dome of the Holy Rock.

\section{Conclusions.}

The aim of this research was to identify the efforts of King Abdullah II Bin Al Hussein in protecting Islamic sanctities, and this was done through three sections using the historical, descriptive, and forward-looking approach, where the origins of the Hashemites were discussed, and their role in the first, second and third reconstruction of Islamic sanctities, then was touched To the efforts of King Abdullah II in the fourth and fifth Hashemite reconstruction, and in the end, the topic of expected prospects for the continuation of King Abdullah II's efforts to protect and reconstruct Islamic sanctities was discussed. The research reached a set of results, the most important of which were:

1 - Throughout history, the Hashemites played their full role in protecting and reconstructing Islamic sanctities. They carried out the first, second and third Hashemite reconstruction.

2- King Abdullah II continued his ancestral march in the protection and reconstruction of Islamic holy sites, so he undertook the fourth and fifth Hashemite reconstruction.

3- Islamic and Christian holy sites in the city of Jerusalem received great attention during the reign of King Abdullah II, and became an integral part of the governments 'work programs during his era.

4- King Abdullah II believes that the two-state solution is the best solution to end the Palestinian issue. 


\section{REFERENCES}

1. Abrash, Ibrahim (2015), internationalization in the context of a comprehensive national strategy, within the book of the fourth annual conference, the Palestinian issue and the international dimension, opportunities and strategic requirements, the Palestinian Center for Policy Research and Strategic Studies.

2. Kingdom TV: The Mecca Summit, (2019), King: A two-state solution is a condition for establishing stability in the region. Article published on the Kingdom TV website on 5/31/2019, available at: https://www.almamlakatv.com/news Posted on 9/30/2019.

3. Ibn Hazm Al-Andalusi, Abu Muhammad Ali bin Ahmed bin Saeed (died: 456 AH), (1983 AD), Ansab alArab, Beirut: House of Scientific Books.

4. Jamal al-Din Abu al-Faraj Abd al-Rahman ibn Ali ibn Muhammad al-Jawzi (died: 597 AH), (1992 CE), regular in the history of nations and kings, investigation: Muhammad Abd al-Qadir Atta, Mustafa Abd alQadir Atta, Beirut: House of Scientific Books.

5. Zahran, Ibrahim, and Al-Amayreh, Sherine (2000), His Majesty King Abdullah II Bin Al-Hussein AlMuazzam, and the Hashemite Reconstruction of Jerusalem and the Holy Places, Amman: Wael House for Publishing and Distribution.

6. Zainuddin Muhammad, called Abd al-Raouf bin Taj al-Arifin bin Ali bin Zain al-Abidin al-Haddadi, then al-Manawi al-Qahiri (died: $1031 \mathrm{AH}),(1356 \mathrm{AH})$.

7. Al-Salous, Aladdin Abdel-Razzaq (2018), Secretions of the Two-State Solution Project and its Impact on Palestinian Options and Alternatives, Master Thesis in Planning and Political Development at the College of Graduate Studies at An-Najah National University, Nablus, Palestine.

8. Shalaby, Salah Abdel-Badi (1983), The Right to Restitution in International Law, A Comparative Study in Islamic Law, International Law, and the Application of its Principles in the Relationship between Arab Countries and Israel, Cairo: Without a publisher.

9. Al-Shannaq, Abd al-Majid Zaid (2003), Introduction to Jordan's History and Civilization, I: 3, Amman: Military Press.

10. Jordan's Al-Ghad newspaper, on the twentieth anniversary of the Royal Seating: Honorable Attitudes towards Jerusalem and the Holy Sites, on June 8, 2019.

11. Al-Abadi, Abdul-Salam (2009), The Hashemite Jordanian Care for Jerusalem and its Islamic Shrines, 4th edition, Amman: Military Press.

12. Abbas, Ibrahim Fouad (2017), Palestinian-American Relations, Giza: The House for Publishing and Distribution.

13. Abbasah et al., Jordan Atlas - History, Earth and Society,

14. Abdel-Hadi, Aouni, and Qasimiya, Charity (2002), Diary of Aouni Abdel-Hadi, Beirut: Center for Arab Unity Studies.

15. Al-Arqan, Abdullah (2002), Jerusalem in International, Arab and Islamic Positions, Amman: Osama House for Printing, Publishing and Distribution.

16. Kassasbeh, Maysa Sheikh Muhammad Ali (2018), the role of the Hashemites in the reconstruction of Islamic holy shrines (Al-Aqsa Mosque and the Dome of the Rock) from the viewpoint of members of the faculty and students in Jordanian universities in the course of the national education course and the proposed ways to activate this role, Master of Education, College Education, Yarmouk University, Irbid.

17. Committee for the Reconstruction of the Blessed Al-Aqsa Mosque and the Dome of the Holy Rock (1994), The Hashemite Reconstruction of the Blessed Al-Aqsa Mosque and the Dome of the Holy Rock, Amman: Ministry of Endowments, Affairs and Islamic Holy Sites.

18. The Hardo Center for Supporting Digital Expression (2018), between media blackout and restrictions on freedom of the press, protest movements against Arab Jerusalem in Egypt, Cairo, the Hardu Center for supporting digital expression.

19. His Majesty King Abdullah II website, The Holy Care, The First Hashemite Reconstruction is available at: https://kingabdullah.jo/en The site was accessed on 25/8/2019; 9/30/2019.

20. Al-Nefaie, Muhammad Bin Ali (2015), The Hashemite Reconstruction in Jerusalem, Amman: Without a publisher. 